\title{
Morphological variations caused by fixation techniques may lead to taxonomic confusion in Laeonereis (Polychaeta: Nereididae)
}

\author{
Verônica M. Oliveira'; Cinthya S. G. Santos²; Paulo C. Lana' \& Maurício G. Camargo \\ ${ }^{1}$ Centro de Estudos do Mar, Universidade Federal do Paraná. Caixa Postal 50002, 83255-000 Pontal do Paraná, Paraná, \\ Brasil. \\ 2 Departamento de Biologia Marinha, Instituto de Biologia, Universidade Federal Fluminense. Caixa Postal 100.644, \\ 24020-150 Niterói, Rio de Janeiro, Brasil.
}

\begin{abstract}
The nereidid polychaete Laeonereis acuta (Treadwell, 1923) is either considered to be a valid species, or a synonym of Laeonereis culveri (Webster, 1879). The species epithet, acuta, refers to the acuminate anterior region of the body followed by a widening that is visible up to the $10^{\text {th }}$ setiger. The relative width of the anterior region of the body, however, has been reported in the taxonomic literature as variable for Laeonereis Hartman, 1945, a genus known from the eastern coast of North America to Patagonia (southern South America). To test whether variations in this character are real, or whether they correspond to an artifact, we analyzed morphological changes associated with different anesthesia and fixation techniques regularly used to prepare specimens of Laeonereis from southern Brazil (formerly reported as L. acuta). Six treatments, including combinations of anesthetics and fixative agents, and a control, were evaluated in groups of 25 adult animals. A simple model II regression analysis on living specimens showed that the growth is approximately isometric. One-way ANOVA was used to compare the treatment effect on the ratio of peristome width: setiger 6 width. This ratio was smaller in non-anesthetized individuals, especially when prepared in formalin and freshwater. When anesthetized with menthol and fixed in formalin with sea water, individuals retained a shape that was closest to their in vivo shape. Consequently, our results suggest that fixation without prior anesthesia is not recommended for morphological and taxonomical studies. Since morphology and morphometrics of the anterior region are consistently influenced by preparation techniques, it is likely that inadequate fixation routines have introduced several errors in the taxonomic and ecological literature of Laeonereis.
\end{abstract}

KEY WORDS. Laeonereis culveri; Laeonereis acuta; morphology; preparation techniques; methodological errors.

Morphological characters are essential for taxonomic and population studies (Mendez \& Cardel 1994, WorsaAe 2001, Glasby et al. 2003, Dong et al. 2006, GARrafFoni \& CAMARgo 2006, CostaPaIva \& PaIva 2007). However, their use presupposes that they are well-defined and repeatable. Polychaetes and other soft-bodied animals may acquire a final shape after fixation that differs from the original shape as a result of fixation routines. While recommendations for reliable techniques of anesthesia and fixation are found in the literature (Martin 2004, Warwick \& Price 1975, TuCKer \& CHESTER 1984), many descriptions and taxonomic revisions are based on specimens that may have been prepared inadequately. In fact, many specimens that are used for taxonomic purposes were originally collected for ecological studies and may not have received the best preparation for taxonomy. For example, polychaetes are often fixed directly in $4 \%$ formalin (in fresh or brackish water solutions), which may cause muscular contractions and deformations, and mask the in vivo animal morphology. In some circumstances, this treatment may hinder the correct identification of the animal (WORSAAE 2001). Species of Laeonereis Hartman, 1945 often have a recti- linear anterior region in vivo, regardless of geographic origin. However, the anterior region of fixed specimens is quite variable in shape, particularly in relative width, ranging from rectilinear to pointed at the apex. Laeonereis acuta (Treadwell, 1923), synonymized with Laeonereis culveri (Webster, 1879) in the extensive review by Peтtibone (1971), has been considered a valid species by some authors (Orensanz \& Gianuca 1974, Omena \& Amaral 2001, Geracitano et al. 2002, 2004a, 2004b, SAntos et al. 2003, PAMPLin et al. 2007). The species epithet, acuta, refers to the shape of the anterior region of the body (including the prostomium, peristomium and the first segments) which is pointed or acuminate, widening posteriorly up to the 10th setiger. In this case, if the shape of the anterior portion of the body is influenced by the fixation technique, the implications for taxonomical decisions are clear.

In this paper we experimentally tested the influence of various preparation techniques on the resultant morphology of specimens collected in the coast of the state of Paraná (southern Brazil), within the geographic range of populations previously referred to as L. acuta (Orensanz \& Gianuca 1974). 


\section{MATERIAL AND METHODS}

Specimens were collected in the inter-tidal zone near the mouth of the Perequê River, Paranaguá Bay, state of Paraná $\left(23^{\circ} 31^{\prime} 49^{\prime \prime} \mathrm{S}, 48^{\circ} 30^{\prime} 43^{\prime \prime} \mathrm{W}\right)$. Next, the specimens were transported to the laboratory inside insulated boxes and were kept alive in Petri dishes that contained brackish water from the collection location. A total of 25 adult specimens were used in each of the six treatments that differed in anesthesia and fixation routines; a control was also used and consisted of live specimens. Basically, the treatments included a combination of using or not using anesthesia followed by fixation with formalin (4\%) diluted either in fresh water or in brackish water: two treatments included no anesthesia; of these, one included formalin (4\%) diluted in fresh water, the other included formalin (4\%) diluted in brackish water. Either menthol $(0.2 \mathrm{mg})$ or magnesium chloride (8\%) were used as anesthetics. The two treatments with menthol were followed by formalin (4\%) diluted either in fresh water or in brackish water. The same applies to the two treatments in which magnesium chloride was used as anesthetic. Time in the anesthetic varied from three hours in menthol to seven hours in magnesium chloride, followed by 48 hours in the fixing solution. Animals were then washed and placed in 70\% alcohol for 24 hours, after which they were measured. The control treatment consisted of living individuals without anesthesia.

Peristomium width (P) and $6^{\text {th }}$ setiger width (S) (excluding parapodia and bristles) were measured under a stereoscopic dissecting microscope. The amount of tapering towards the anterior region was calculated as the ratio $\mathrm{P} / \mathrm{S}$. Values near 1.0 indicate a rectilinear region and values lower than 1.0 indicate a more pointed anterior region (Figs 1 and 2).
The relationship between $\mathrm{P}$ and $\mathrm{S}$ was established for live animals through a model II regression analysis which is used when both variables are random. As both variables were normal (Shapiro test, p > 0.05) and measured using the same scale, the major axis (MA) technique was chosen to perform the regression (LEgENDRE \& LEgendRe 1998). We hypothesized that if $P$ and $\mathrm{S}$ were found to be correlated, the animals would have an approximately isometric growth, what would allow us to go further, comparing treatments using the ratio $\mathrm{P} / \mathrm{S}$ as a dependent variable in a one-way analysis of variance.

Treatment effects were compared using separated ANOVA's for fresh and brackish water, both followed by Tukey post-hoc tests when significant (UNDERWOOD 1997). The assumptions of ANOVA were tested and Log transformations were applied when necessary.

\section{RESULTS AND DISCUSSION}

The results of the regression between peristomium width (P) and $6^{\text {th }}$ setiger width (S) under Model II was highly significant $\left(r^{2}=0.85, p<0.001\right.$, Fig. 3), indicating that specimens have nearly isometric growth. Table I summarizes ANOVA results for the brackish and fresh water treatments, respectively. In both, global effect was significant and individual differences are shown in figure 4 .

Values for setiger 6 to peristomium width were constant among all control animals (Fig. 4). After fixation, shapes varied between rectilinear, intermediate or pointed (figures 1 and 2 show the two extremes). The P/S ratio (not including specimens anesthetized with menthol and fixed in saline formalin) was smaller in animals fixed directly in formalin (4\%) diluted in fresh water. When anesthesia was not used, both fixing so-
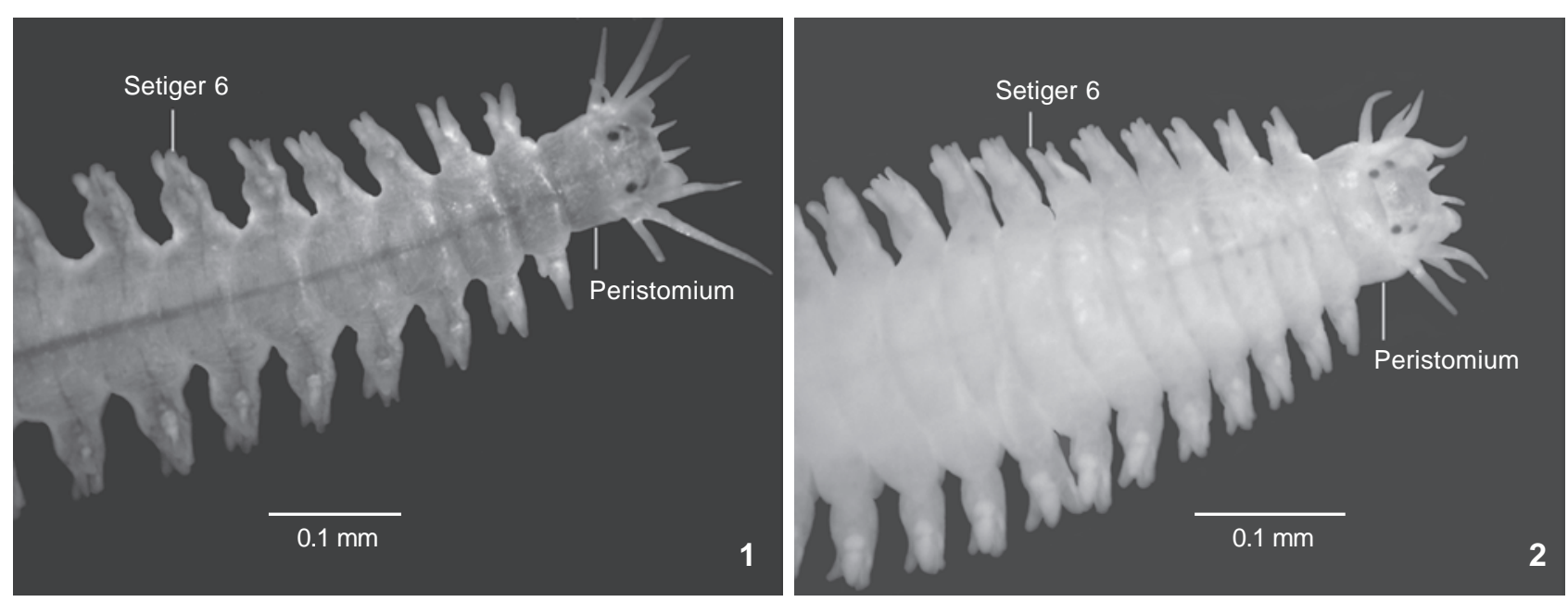

Figures 1-2. Dorsal views of L. culveri: (1) Live specimen without anesthesia. Note the rectilinear format of the anterior end; (2) specimen in $70 \%$ alcohol followed by $4 \%$ formalin in fresh water, without anesthesia. Note the inflated anterior region. 
Table I. One-way ANOVA summary comparing treatments for the ratio between peristome width and $6^{\text {th }}$ setiger width in brackish and fresh water.

\begin{tabular}{|c|c|c|c|c|c|c|c|c|}
\hline \multirow{2}{*}{ Source } & \multicolumn{4}{|c|}{ Brackish water } & \multicolumn{4}{|c|}{ Fresh water } \\
\hline & Degree of freedom & Mean square & $\mathrm{F}$ & $\mathrm{p}$ & Degree of freedom & Mean square & $\mathrm{F}$ & $\mathrm{p}$ \\
\hline Treatment effect & 3 & 0.3700 & 46.94 & $<0.001$ & 2 & 0.18 & 9.52 & $<0.001$ \\
\hline Residuals & 96 & 0.0079 & & & 72 & 0.02 & & \\
\hline
\end{tabular}
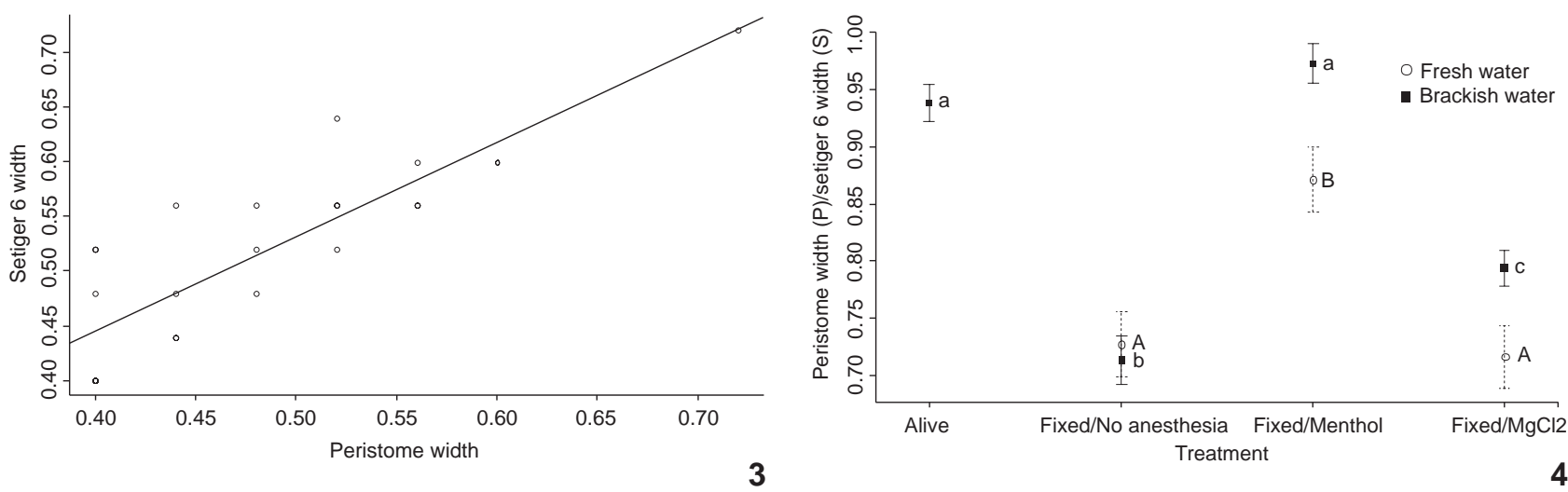

Figures 3-4. Relation between peristomium width $(P)$ and $6^{\text {th }}$ setiger width $(S)$ for live animals. Regression line was estimated through a model II regression using standard major axis technique $\left(r^{2}=0.85 ; p<0.001\right)$. (4) Mean and standard error of ratio $P / S$ among treatments for fresh and brackish water. For each group, $n=25$. Different letters near means indicate significant differences among $P / S$ ratios according to Tukey test $(p<0.05)$. Lower-case letters compare treatments from brackish water and upper-case letters from fresh water.

lutions caused a relative widening of setiger 6 that reduced the $\mathrm{P} / \mathrm{S}$ ratio. The greatest effect was in fresh water treatment without anesthesia, possibly due to osmotic shock (Fig. 4).

The anterior region was acuminate when not anesthetized and fixed directly in formalin in either brackish or fresh water. This region had intermediate $\mathrm{P} / \mathrm{S}$ ratios when anesthetized in magnesium chloride with either brackish or fresh water. A rectilinear shape was the result of anesthesia in menthol followed by fixing in saline formalin solution (Fig. 4).

Few studies have evaluated the importance of anesthesia and fixing methods on the morphology of polychaetes. Contraction and expansion of the polychaete Capitella capitata (Fabricius, 1780) were compared after five different treatments of specimen preparation (Mendez \& CARdel 1994). Inadequate fixing of specimens may also hinder identification. For example, prostomium morphology and eye position vary as a consequence of fixing in Namalycastis hawaiiensis (Johnson, 1903) (Glasby et al. 2003). Specimens of Branchiomma luctuosum (Grube, 1869) maintained a shape more similar to that in vivo when anesthetized in fresh water and fixed with ethanol (CosTAPAIVA et al. 2007). The latter study also showed that, when refrigerated and placed in formalin $4 \%$, specimens contracted, becoming short and thick. Finally, when anesthetized in menthol and magnesium chloride (commonly used anesthetics), specimens relaxed even more and became longer and flatter. Only three regions of the body remained more or less unaltered due to the varying different treatments (the radiolar crown, the first setiger and the pygidium) and thus were considered more informative for morphological studies.

Omena \& Amaral (2001) suggested that the width of setigers 6 and 7 in L. acuta (= L. culveri) are less affected by fixation and hence are more strongly correlated with total body length. Their conclusions contrast with our results which show that, while the retracted proboscis may reach slightly past setiger 3 in vivo, it may pass setiger 6 in fixed animals due to contraction of the previous setigers, and may even extend up to setiger 10.

The tapering of the anterior region of the body is one of the criteria originally used to describe $L$. acuta, along with variability in the posterior parapodial lobes (Orensanz \& GianUCA 1974). An analysis of Laeonereis spp. along the entire distribution of the genus has demonstrated wide intraspecific variation in the shape of the parapodia. Based on these results, we propose that $L$. acuta should be considered a junior synonym of $L$. culveri. In the future, and for additional validation of this synonym, we recommend that specimens of Laeonereis are prepared with anesthesia in menthol, followed by fixing in formalin in saline solution prior to storage in alcohol. 
We suggest that a clear understanding of the effects of anesthesia and fixation is mandatory for taxonomic purposes; and that we need to make every effort to use preparation techniques that do not distort the original shape of the specimens. In order to adopt this procedure, we need to compare in vivo morphology with that in vitro. Techniques used in anesthesia and fixation must be clearly and completely described in the methods section of morphological studies to avoid the propagation of mistaken identifications. We believe that it is quite possible that other polychaete species have been mistakenly identified because of previously unrecognized effects associated with preparation and storage of specimens.

\section{ACKNOWLEDGMENTS}

We thank CAPES, the Centro de Estudos do Mar (Universidade Federal do Paraná - UFPR), and the Graduate Program in Zoology at the UFPR for their support. We also thank Maikon Di Domenico for his help with statistical analysis; Fernando C.C. dos Santos for his help collecting specimens; Luciana S. Lima and Heliatrice R. Hadlich for their help with Photoshop. James J. Roper translated this article from the original Portuguese and offered constructive criticism to improve the text.

\section{LITERATURE CITED}

Costa-Paiva, E.M. \& P.C. Paiva. 2007. A morphometric analysis of Eunice Cuvier (Annelida, Polychaeta) species. Revista Brasileira de Zoologia 24: 353-358.

Costa-Paiva, E.M.; P.C. Paiva \& M. Klautau. 2007. Anaesthetization and effects on the morphology of sabellid polychaetes (Annelida: Polychaeta: Sabellidae). Journal of the Marine Biological Association of the United Kingdom 87: 1127-1132.

Dong, Q.; C. Hunng; M.C. Henk \& T.R. Tiersch. 2006. Fixation methods can produce misleading artifacts in sperm cell ultrastructure of diploid and tretraploid Pacific oyster, Crassostrea gigas. Cell and Tissue Reseach 324 (2): 335-345.

FAbricius, O. 1780. Fauna groenlandica, systematice sistems, animalia groenlandiae occidentalis hactenus indagata, quoad nomen specificum, triviale, vernaculumque synonyma auctorum plurium, descriptionem, locum, victum, generationem, mores, usum, capturamque singuli prout de. Hafnie et Lipsia. 452p

Garraffoni, A.R.S. \& M.G. CAmargo. 2006. First application of morphometrics in a study of variations in uncinial shape present within the Terebellidae (Polychaeta). Zoological Studies 45 (1): 75-80.

Geracitano, L.A.; J.M. Monserrat; A. Bianchint. 2002. Physiological and antioxidant enzyme responses to acute and chronic exposure of Laeonereis acuta (Polychaeta, Nereididae) to copper. Journal of Experimental Marine Biology and Ecology 277: 145-156.

Geracitano, L.A.; J.M. Monserrat; A. Bianchini. 2004a. Oxidative stress in Laeonereis acuta (Polychaeta, Nereididade): environmental and seasonal effects. Marine Environmental Research 58 (2): 625-630.

Geracitano, L.A.; C. Luquet; J.M. Monserrat; A. Bianchini. 2004 b. Histological and morphological alterations induced by copper exposure in Laeonereis acuta (Polychaeta, Nereididae) Marine Environmental Research 58 (2): 263-267.

Glasby, J.C.; M. Mogi; K. Takahashi. 2003. Occurrence of the Polychaeta Namalyscastis hawaiiensis, Johnson 1903 (Nereididae: Namanereidinae) in Pandanis leaf axils on Palau, West Pacific. The Beagle, Records of the Museum and Art Gallery of the Northern Territory 19: 97-99.

Grube, E. 1869. Beschreibungen neuer oder weniger bekannter von Hrn. Ehrenberg gesammelter Anneliden des rothen Meeres. Monatsberichte der Königlich Preussischen Akademie der Wissenschaften zu Berlin aus dem Jahre, p. 484-521.

Johnson, H.P. 1903. Freshwater nereids from the Pacific coast and Hawaii, with remarks on fresh-water Polychaeta in general. New York, Henry Holt, Mark Anniversary volume, p. 205-222.

Legendre, P. \& L.Legendre 1998. Numerical Ecology. Developments in Environmental Modelling 20. $2^{\text {nd }}$ edition. Elsevier, New York. XV + 853p.

Martin, J.W. 2004. Fixation versus preservation. Available online at: http://clade.ansp.org/malacology/people/rosenberg/ archiving/method/fixation_preservation.html [Accessed: 11/ $\mathrm{X} / 2009]$

Méndez, M.N. \& M.J. Cardell. 1994. Effects of sample fixation on body shape of Capitella capitata (Capitellidae). Mémoires du Museum National d'Histoire Naturelle 162: 111-117.

Omena, E.P. \& A.C.Z. Amaral. 2001. Morphometric study of the nereidid Laeonereis acuta (Nereididae: Polychaeta). Journal of the Marine Biological Association of the United Kingdom 81: 423-426.

Orensanz, J.M. \& N.M. Gianuca. 1974. Contribuição ao conhecimento dos anelídeos poliquetas do Rio Grande do Sul, Brasil. I. Lista sistemática preliminar e descrição de três novas espécies. Comunicações do Museu de Ciências da FURGS 4: 1-37.

Pamplin, P.A.Z.; T.C.M. Almeida.; J.P. Silva-Filho. 2007. New record of Laeonereis acuta (Treadwell, 1923) (Nereididae: Polychaeta) in Northeast coast of Brazil. Biota Neotropica 7 (3): 353355.

Pettibone, M.H. 1971. Revision of some species referred to Leptonereis, Nicon and Laeonereis (Polychaeta: Nereididae). Smithsonian Contributions to Zoology 104: 1-53.

Santos, P.J.P.; M.S. Florêncio; M.A.P. Florêncio. 2003. Reproductive cycle of the polychaete Laeonereis acuta on a tropical intertidal sandy beach. Journal of Costal Research 35: 378-384.

Treadwell, A.L. 1923. Two new species of polychaetous annelids of the genus Nereis from Brazil. Revista do Museu Paulista 13: $1237-1243$. 
TuCKer Jr, J.W. \& A.J. Chester. 1984. Effects of salinity, formalin concentration and buffer on quality of preservation of southern flounder (Paralichthys lethostigma) larvae. Copeia 1984 (4): 981-988.

UNDERWOOD, A.J. 1997. Experiments in ecology: their logical design interpretation using analysis of variance. New York, Cambridge University Press, 504p.

Warwick, R.M. \& R. Price. 1975. Macrofauna production in an

Submitted: 23.III.2009; Accepted: 26.I.2010.

Editorial responsibility: Marcos Tavares estuarine mud-flat. Journal of the Marine Biological Association of the United Kingdom 55: 1-18.

Webster, H.E. 1879. The Annelida Chaetopoda of New Jersey. Annual Report of the New York State Museum of Natural History 32: 101-128.

WorsaAe, K. 2001. The systematic significance of palp morphology in the Polydora complex (Polychaeta: Spionidae). Zoologischer Anzeiger 240 (1): 47-59. 